
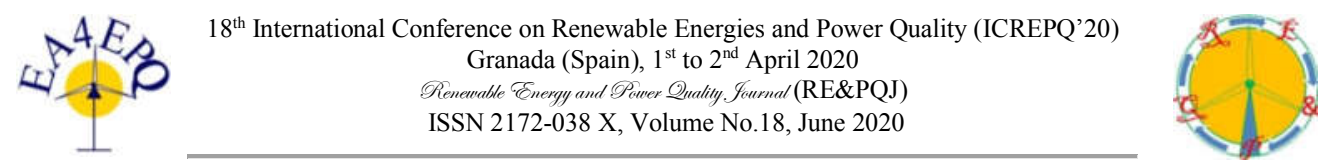

\title{
Modelling for Classifying Different Shadow of Obstacles on a c-Si PV Panel
}

\author{
M.R. Rashel ${ }^{1,5}$, Md T. Ahmed ${ }^{1}$, S.S. Satter ${ }^{3}$, Saiful Islam ${ }^{4}$, M. Tlemçani ${ }^{1}$ and R. Melicio ${ }^{1,2}$ \\ ${ }^{1}$ ICT and Departamento de Física, Escola de Ciências e Tecnologia, \\ Universidade de Évora, Portugal \\ ${ }^{2}$ IDMEC, Instituto Superior Técnico, Universidade de Lisboa, Portugal \\ ${ }^{3}$ Department of Electrical and Electronic Engineering, \\ University of Dhaka, Bangladesh \\ ${ }^{4}$ Department of Information and Communication Technology, \\ Bangladesh University of Professionals, \\ ${ }^{5}$ Department of Computer Science \& Engineering \\ Daffodil International University Bangladesh, Bangladesh \\ e-mail: masudranarashel@gmail.com, tahmedbu@gmail.com, \\ saifulislam@bup.edu.bd, sakin.sarwar1993@gmail.com, tlem@uevora.pt, ruimelicio@gmail.com
}

\begin{abstract}
Shadow of Obstacles (SoO) on a PV Panel is classified depending on time with changing pattern of the shadow. Due to obstacles, the performance of a silicon c-Si PV panel reduces by a significant level. Different types of obstacles cast shadow on the panel and interrupt to get irradiation reducing the generated power. The simulation model is implemented in MATLAB/Simulink to observe the changing pattern and variation of output power with changing shadow pattern of the obstacles. The results show identical behaviors. It is clearly viewed in both $\mathrm{PV}$ generated $\mathrm{I}-\mathrm{V}$ and $\mathrm{P}-\mathrm{V}$ curves. Their pattern of graphs is changed depending on the time for time-dependent obstacles. Graphs pattern is also changed with depending on timeindependent obstacles and that does not vary with time. The identification of the behavior of the obstacle is vital to improve the PV system performance. For time-dependent obstacles and for time independent obstacles power decreases in specific quantity depending on the kind of SoO. Specifically, for the timedepending one is also depend on the duration of the SoO.
\end{abstract}

Key words. PV Panel, Shadow of Obstacles, TimeDependent Obstacles, Time-Independent Obstacles.

\section{Introduction}

Last few decades the world had a huge technical progress, that makes it more dependent on energy. Existing nonrenewable energy sources are not safe for environment and they generate huge amount of greenhouse gases (GHG). People are taking initiatives to reduce these kinds of hazardous GHG by utilizing renewable energy sources. Meeting between all policy maker and all of the countries come to a common point to help the earth to reduce the GHG and the temperature of the world. In the meeting one of the important issues was to use more renewable energy over fossil fuel resources.

Photovoltaic cell (PV) is a simple device that transforms solar energy to electrical energy on the principle of Photo effect. PV is a fast-growing technology all over the world due to its rapid reduction of cost and improving performance in real time. Another important is that it does not emit any GHG during the production time [1-6].

In [7] it is stated that in Libya there are different types of dust patterns in photovoltaic panels. It compares both dust and clean scenario of a PV panel and gives detail of loss analysis due to the dust obstacle. It shows that due to dust the performance of the panel decline a lot and reduces the total performance of a system.

In $[8,9]$ it is described about the shadow effect over series connected monocrystalline silicon solar modules. The result of the simulation shows that due to shadow the performance decrease a lot and also several peaks is viewed in $\mathrm{I}-\mathrm{V}$ and $\mathrm{P}-\mathrm{V}$ curves. This introduces the local maxima and misguides the maximum power point tracking (MPPT) system. In [10] it is stated the partial shading effect using five parameters single diode PV model. It also shows that due to shadow the performance of PV reduces a lot.

In [11] it is stated about dust growth on the PV panel and their effect. It introduces the photovoltaic soiling index (PVSI) that try to standardize the health condition of a panel under a different type of scenario and at various location. In [12] it is stated that the relation between obstacles and number of cells affected by the shadow on a PV panel. In this work, MATLAB is used to simulate the scenario. 
In [13] it is described both direct and diffuse radiation for PV panels. This work observes the shadow effect of different obstacles' of the city area. 3D city model is used to observe the properties and identify causes of the obstacles that makes shadow. In [14] it is described the shadow effect on PV panels. In this work, it switching matrix technique is introduced to get rid of shadowing effect. And also improve the performance of MPPT techniques.

In [15] it is stated detail analysis of PV panel's performance with shadow effect. It describes that shadow introduces uncertainty to forecast the power of a PV panel.

In [16] discusses bird droppings on PV panel. For a big PV plant this occurrence the performance of the system reduces. This is one kind of shading effect that makes an obstacle for irradiance to reach the surface. This paper simulates the scenario for the silicon monocrystalline solar (c-Si) panel in a laboratory environment. They use a different arrangement of PV arrays connection to increase the performance under bird dropping condition.

In [17] discusses partial shading condition and provides a solution to overcome the local maxima problem. During shadow condition, $\mathrm{P}-\mathrm{V}$ curve has more than one peak and misguide the MPP tracker to get the maximum power. Because of shadow, more than one peak is observed. In [18] discusses the shadow over the cell of PV and state of the series and parallel arrangement of the cell under shading condition. In [19] it is described, a simulator that is for simulating dynamic and partial shadow condition for PV panels. It gives the idea about the real scenario when a panel is under shadow condition.

All these literature reviews identify the shadow of obstacles as a negative element that reduce the performance of PV panel and make the system more unpredictable.

This paper, classifieds the SoO dependent on time using I$\mathrm{V}$ and $\mathrm{P}-\mathrm{V}$ curves, and generalize the shadow and their effects on panels. There are different types of elements such as cloud, dust, bird, tree or damaged cell of PV panel itself reduce the performance of a panel. The simulation model for a PV panel is implemented in MATLAB/Simulink. This is for observing the SoO effects on PV Panels. Dynamic and statistical models are created depending on time using I-V and $\mathrm{P}-\mathrm{V}$ curves pattern. The simulation outputs give new pattern of $\mathrm{P}-\mathrm{V}$ and $\mathrm{I}-\mathrm{V}$ curves. It is very important for identification of a fault in PV panel whether it is permanent or temporary affect. Section 2 models the PV panel using double diode five parameters and describe the SoO. Section 3 presents case studies from the simulation. Finally, conclusions are described in Section 4.

\section{Modelling}

Photovoltaic cell working principle is elementary, as an electrical device, it converts solar irradiance to electric energy based on photo effect [20-27].

The solar irradiance with sufficient energy falls on the surface of PV cell that excites electrons. In this process it generates electrons and holes, resulting in electric current. A five parameters double diode PV equivalent circuit diagram [28-37] is presented in the Fig. 1.

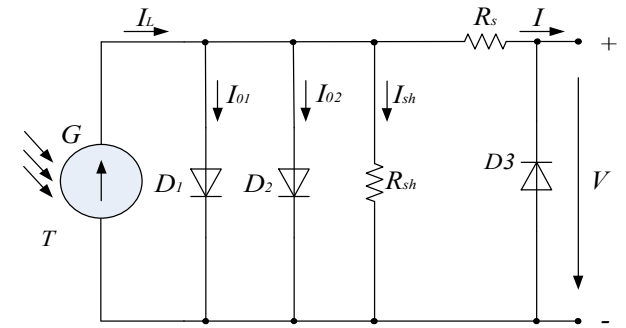

Fig. 1. Double diode five parameters PV eq. circuit diagram [51].

In Fig. $1, I_{L}$ is photoelectric current, $I_{01}$ and $I_{02}$ are diode saturation current, $R_{s}$ is a series resistance, $R_{s h}$ is shunt resistance, $I$ gives output current of the cell having the load voltage $V, G$ is irradiance $\left(\mathrm{W} / \mathrm{m}^{2}\right), I_{s h}$ is current through the shunt resistance, $T$ is temperature of $\mathrm{p}-\mathrm{n}$ junction, $D_{1}$ and $D_{2}$ are the diodes, $D_{3}$ is the bypass diode [37-50]. The output current is given by:

$$
I=I_{L}-I_{D 1}-I_{D 2}-\left(\frac{V+R_{S} I}{R_{S h}}\right)
$$

where

$$
\begin{aligned}
& I_{D 1}=I_{0} 1\left[e^{\left(\frac{\left(V+R_{S} I\right.}{n_{1} K T}\right)}-1\right] \\
& I_{D 2}=I_{02}\left[e^{\left(\frac{\left(V+R_{S} I\right.}{n_{2} K T}\right)}-1\right]
\end{aligned}
$$

where $n_{1}$ and $n_{2}$ are diode ideality factors for diodes in the Fig. 1, $K$ is Boltzmann constant, $e$ is electron charge. Different kinds of obstacles create a barrier to get the irradiance to PV panel, physical damage to cells also reduces the panel to get irradiance. There are temporary obstacles that go with the time and permanent obstacles that need human help to fix the problem and increase the performance.

Time-dependent obstacle: The obstacles whose pattern changes with time are called time-dependent obstacles. These types are depending on time and change the pattern of the I-V and P-V curves with variation of time, is given by:

$$
\boldsymbol{P}_{o} \propto \boldsymbol{O}_{o b s}(\boldsymbol{t})
$$

where $P_{o}$ is the power output from a PV panel and $O_{o b s}(t)$ shadow of the obstacle with time that vary the irradiance.

\section{Case Studies}

In this section it is studied the behavior of the double diode five parameters PV panel model (Fig. 1) implemented in MATLAB/Simulink. In this article, I-V characteristic curves are obtained through the Newton-Raphson iterative method. The c-Si PV panel is performed by 72 cells and they are connected in series. The data for c-Si solar cell at standard test condition (STC) [48] is given in Table 1.

Table 1. Data for c-Si solar cell at STC condition

\begin{tabular}{|c|c|c|c|c|c|c|}
\hline $\begin{array}{c}\boldsymbol{V}_{\boldsymbol{m}}^{*} \\
(\mathrm{~V})\end{array}$ & $\begin{array}{c}\boldsymbol{I}_{\boldsymbol{m}}^{*} \\
(\mathrm{~A})\end{array}$ & $\begin{array}{c}\boldsymbol{V}_{\boldsymbol{O C}}^{*} \\
(\mathrm{~V})\end{array}$ & $\begin{array}{c}\boldsymbol{I}_{\boldsymbol{S C}}^{*} \\
(\mathrm{~A})\end{array}$ & $\boldsymbol{n}_{\mathbf{1}}$ & $\boldsymbol{n}_{\mathbf{2}}$ & $\boldsymbol{N}_{\boldsymbol{s}}$ \\
\hline 35.2 & 7.1 & 0.60 & 7.34 & 1.5 & 1.5 & 72 \\
\hline
\end{tabular}


In Table $1, V_{m}$ is voltage at maximum power, $I_{m}$ is current at maximum power, $V_{o c}$ is open circuit voltage, $I_{s c}$ is short circuit current and $N_{s}$ is a number of cells in the PV panel.

\subsection{Without Any Obstacle}

Simulation of the panel, I-V and P-V curves without any obstacle's shadow and at STC condition are shown in the Fig. 2.
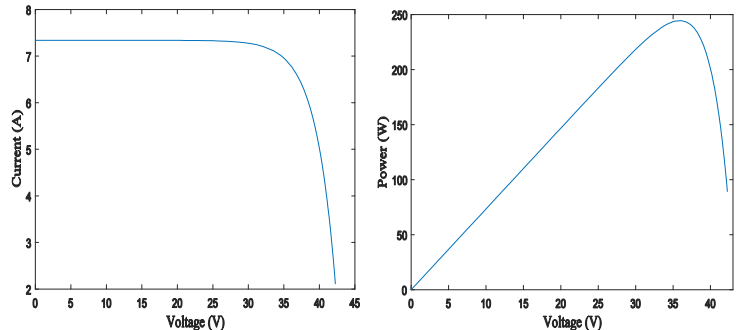

Fig. 2. Different curves at STC condition without SoO: left) I-V curve; right) $\mathrm{P}-\mathrm{V}$ curve.

\subsection{With Time-Dependent Obstacles}

In this section, simulations of the PV under time-dependent obstacles in two different Scenarios are presented to evaluate the behavior of $\mathrm{I}-\mathrm{V}$ and $\mathrm{P}-\mathrm{V}$ curves due to timedependent obstacles.

Scenario 1: This simulation is designed to simulate a big cloud crosses over the PV panel and makes a shadow on it. The irradiance is changing in continuous manner. Simulation is done with Simulink, I-V curve for this situation is shown in the Fig. 3 below [6].

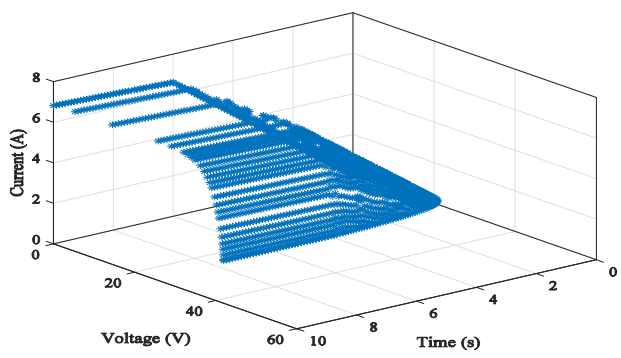

Fig. 3. I-V curves shaded by a time-dependent obstacle.

Due to the cloud is going over the PV panel, I-V curves are changing with different time step.

In the same condition the P-V curves is presented in Fig 4 [6].

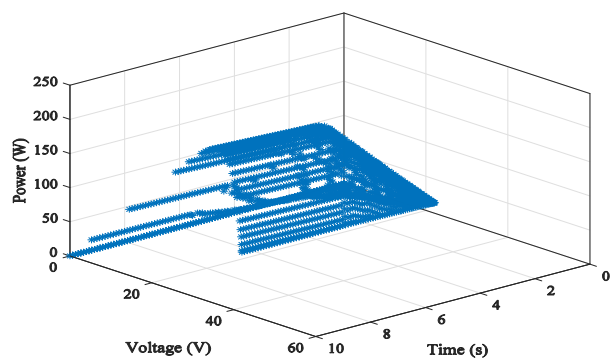

Fig. 4. P-V curves shaded by a time-dependent obstacle.
In Fig. 3 and Fig. 4 presents that I-V and P-V curves, those are changing with time, i.e., with changing the shadow pattern of the cloud due to the cloud is going over the PV panel.

Scenario_2: This simulation is designed to simulate when the shadow pattern of the obstacles is changing rapidly as one after another cloud is going over the PV panel. The I$\mathrm{V}$ curve (panel shaded) under rapid changing obstacles and with time is presented in Fig. 5. The P-V curves (panel shaded) with time under rapid changing obstacles are shown in Fig. 6 [6,51].

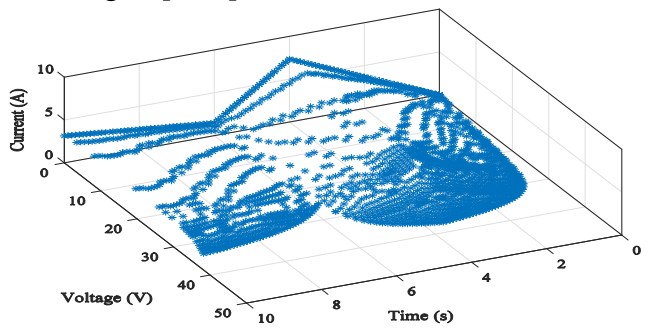

Fig. 5. I-V curves (part of panel shaded) during rapid changing obstacle with time.

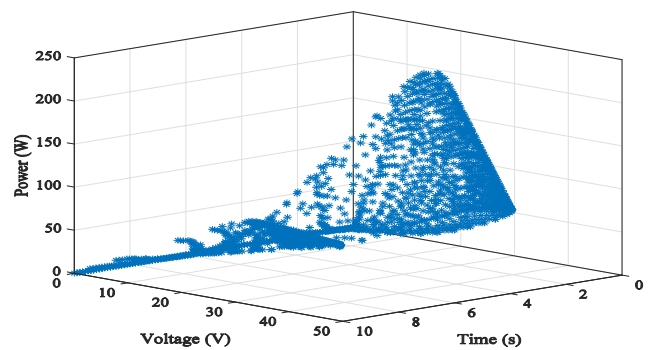

Fig. 6. P-V curves (panel shaded) during rapid changing obstacle with time.

Scenario_2: in Fig. 5 and Fig. 6 shows that the shape of the I-V curves and P-V curves are changing with the changing pattern shadow of the obstacles [6].

\subsection{With Time-Independent Obstacles}

In this section, simulations of the PV panel shaded in three different Scenarios. The Scenarios presented to evaluate the characteristics of $\mathrm{I}-\mathrm{V}$ and $\mathrm{P}-\mathrm{V}$ curves due to timeindependent obstacles.

Scenario_1: Panel shaded by a uniform thin layer of dust is over the PV panel.

The I-V curve of the shaded panel by time-independent obstacles under thin layer of uniform dust is over the PV panel is presented in Fig. 10. The P-V curve with timeindependent obstacles under thin layer of uniform dust is over the PV panel is presented in Fig. 11 [6].

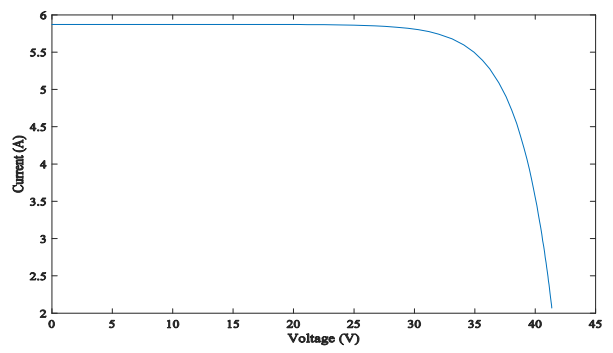


Fig. 7. I-V curve under a thin layer of uniform dust.

Comparing Fig. 2 (left) and Fig. 2 (right) with Fig. 7 and Fig. 8 shows that when the panel is shaded by a thin layer of dust the output of the panel decreases, i.e., I-V and P-V curves have a different behavior, because the dust reduces the irradiation on the panel $[6,51]$.

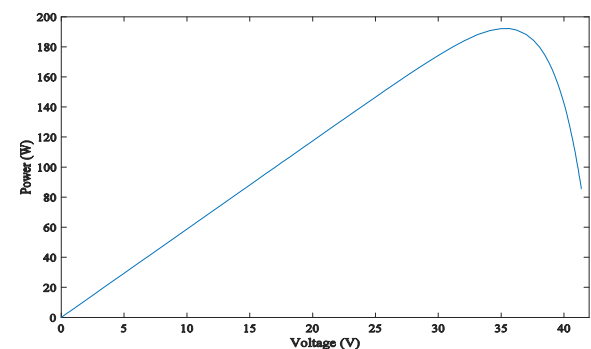

Fig. 8. P-V curve under a thin layer of uniform dust.

Scenario_2: Among 72 cells of the PV panel, 20 cells are under time-independent obstacle (static obstacle) shadow, 52 cells are under STC irradiation condition. The cells are connected using a bypass protection diode. The I-V curve of the panel with 20 cells shaded by a static obstacle and 52 cells under STC irradiation condition is presented in Fig. 9. The P-V curve of the panel with 20 cells shaded by a static obstacle and 52 cells under STC irradiation condition is presented in Fig. 10 [6,51].

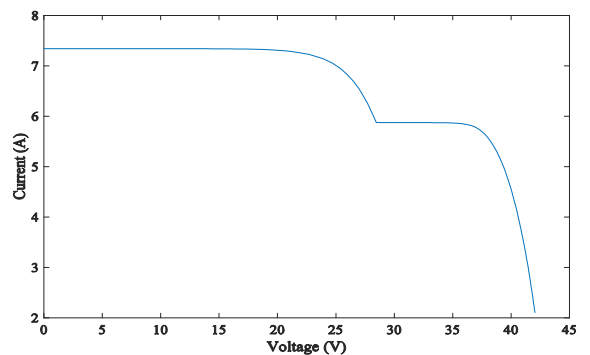

Fig. 9. I-V curve with 20 cells shaded by a static obstacle and 52 cells under STC condition.

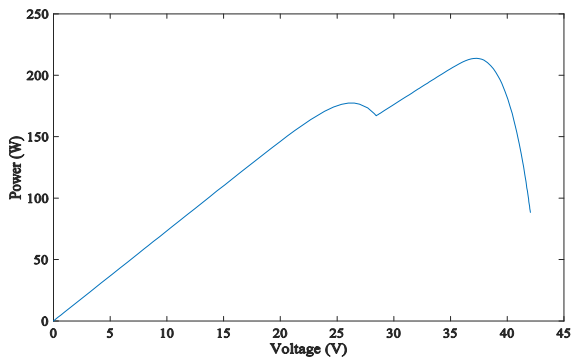

Fig. 10. P-V curve with 20 cells shaded by a static obstacle and 52 cells under STC condition.

Comparing Fig. 2 (left) and Fig. 2 (right) with Fig. 9 and Fig. 10 shows that when the panel has 20 cells shaded by a static obstacle and 52 cells at STC condition the output of the panel decreases [6,51].

Scenario_3: Among 72 cells of the PV panel, 54 cells are under time-independent obstacle (static obstacle) shadow, 18 cells under STC irradiation condition. The cells are connected using a bypass protection diode.
The I-V curve of the panel with 54 cells shaded by a static obstacle and 18 cells at STC irradiation condition is shown in Fig. 11. The P-V curve of the panel with 54 cells shaded by a static obstacle and 18 cells under STC irradiation condition is shown in Fig. 12 [6,51].

Comparing Fig. 2 (left) and Fig. 2 (right) with Fig. 11 and Fig. 12 shows that when the panel has 54 cells shaded by a static obstacle and 18 cells at STC condition the output of the panel decreases.

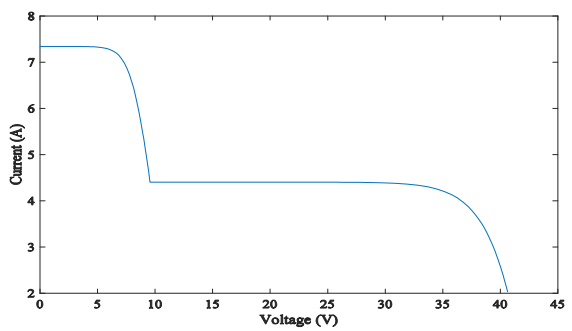

Fig. 11. I-V curve, among total 72 cells, 54 cells are shaded by a static obstacle and 18 cells under STC condition.

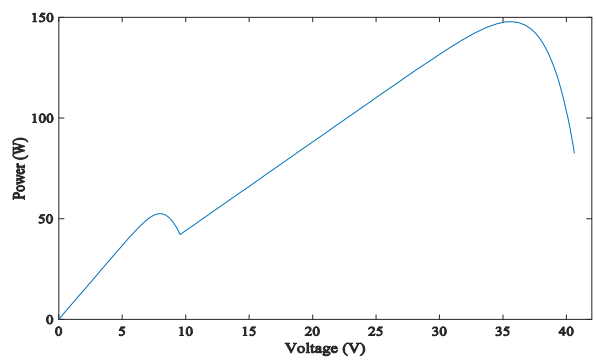

Fig. 12. P-V curve, among total 72 cells, 54 cells are shaded by a static obstacle and 18 cells under STC condition.

\subsection{PV Panel Under Three Conditions}

In this scenario, PV panel is under three different types of condition, one part is under STC condition, one part is under the time-dependent obstacle and one part is under the time-independent obstacle. The cells are connected using bypass protection diodes. The I-V curves under STC condition having time-independent obstacle and timedependent obstacle ( 3 errors occurs over PV panel in same time) is presented in Fig. 13 [6,51].

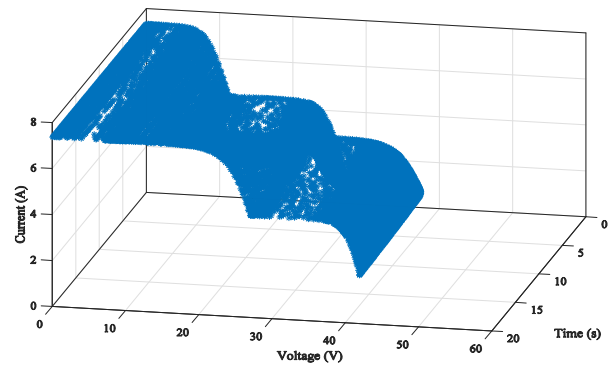

Fig. 13. I-V curve under STC condition, having no error, timeindependent obstacle, and time-dependent obstacle.

The P-V curve under STC condition having no error, timeindependent obstacle and time-dependent obstacle is presented in Fig. 14.

Comparing Fig. 2 (left) and Fig. 2 (right) with Fig. 13 and Fig. 14 shows that when the panel is under three different 
types of condition, one part is under STC condition the I-V and P-V curves are depended on the pattern and characteristics of SoO and the output of the panel decreases. In this section, all the figures show identical behaviors and their shape of the I-V and P-V curve is changing with the pattern of the SoO. The identification of the behavior of the obstacle is vital to improve the PV system performance $[6,51]$.

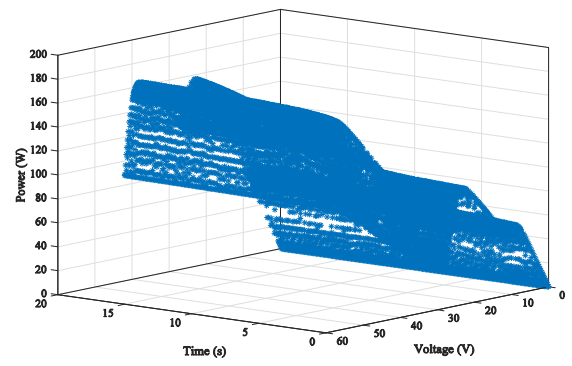

Figure 14. P-V curve under STC condition having no error, timeindependent obstacle and time-dependent obstacle.

\section{Conclusion}

PV panel depends on the weather variables, which are nonlinear in behavior and difficult to forecast. With the dependent variables, its output is also nonlinear and difficult to predict future output. Shadow of obstacles are the elements that reduce the irradiance to reach the working surface of PV panel and decrease the performance dramatically. Due to the presence of random shadow of obstacles the generation of the system becomes unpredictable. Shadow of obstacles the generalize form that define the fault in panel. Fault always decreases the system performance. It is important and crucial to identify the faults and the solution to overcome them. First step to solve the problem is to identify the problem clearly. For every scenario the percentage of the power loss due to $\mathrm{SoO}$ is very on their behavior. In time dependent SoO the power loss is depending on the duration of the SoO. For a specific situation (10 second of dynamic SoO and among 72 cells, 48 cells under SoO) and its decrease the power around 13.9 percent. And for time independent (among 72 cells, 48 cells under $\mathrm{SoO}$ ) the power loss is 38.5 percent on a specific $\mathrm{SoO}$, but it is permanent till the problem is not solve manually.

The behavior and shape of the obstacles has been classified in this paper. Time-dependent and time-independent shadow of obstacles both decrease the power generation. For Time-dependent shadow of obstacles, it is needed to arrange the cells or other electrical improvement that can overcome the problem and reduce the loss. Timeindependent shadow of obstacles needs to be fixed manually or using artificial intelligent machine.

\section{Acknowledgements}

The first and second author would like to thank EASY-AIM and ALT20-03-0247-FEDER-017659-BRO-CQ-IDTCOP-17659 for funding the work and ICT of University of Évora for enabling this work. This work is funded by: European Union through the European Regional Development Fund, included in the COMPETE 2020
(Operational Program Competitiveness and Internationalization) through the ICT project UID/GEO/04683/2019 with the reference POCI010145FEDER007690; Portuguese Funds through the Foundation for Science and Technology-FCT under the project LAETA 2015 $\square 2020$, reference UID/EMS/50022/2019; Portuguese Foundation for Science and Technology (FCT) under Project UID/EMS/00151/2019.

\section{References}

[1] M. Hoel, S. Kverndokk, "Depletion of fossil fuels and the impacts of global warming," Resource and Energy Economics, vol. 18, No. 2, pp. 115-136, June 1996.

[2] United Nation, A new global climate change agreement, Framework Convention on Climate Change, 12 December 2015.

[3] S. Dresner, The principles of sustainability, 2nd ed., Earthscan, London, UK, 2008.

[4] C. Figueres, "Addressing climate change is our task,"

URL:https://blogs.thomsonreuters.com/answerson/christiana-

figueres-addressing-climate-change-is-our-task/

(Accessed:03.01.2018).

[5] Solar Glass Shield,

URL:https://www.solarglassshield.com/construction-miningdust (Accessed:10.11.2017).

[6] M.R. Rashel, "Modeling photovoltaic panels under variable internal and environmental conditions with non-constant load", $\mathrm{PhD}$ thesis, University of Evora, 27 July, 2018.

[7] A.O. Mohamed, A. Hasan, "Effect of dust accumulation on performance of photovoltaic solar modules in Sahara environment," Journal of Basic and Applied Scientific Research, vol. 2, No. 11, pp. 11030-11036, 2012.

[8] L.A.P. Fialho, R. Melicio, V.M.F. Mendes, J. Figueiredo, M.I.C. Pereira, "Amorphous solar modules simulation and experimental results: effect of shading," Technological Innovation for Collective Awareness Systems, SPRINGER, pp. 315-323, April 2014.

[9] L.A.P. Fialho, R.Melicio, V.M.F. Mendes, J. Figueiredo, M.I.C. Pereira, "Effect of shading on series solar modules: simulation and experimental results," Procedia Technology, vol. 17, pp. 295-302, December 2014.

[10] L.A.P. Fialho, R. Melicio, V.M.F. Mendes, "PV system modeling by five parameters and in situ test," International Symposium on Power Electronics, Electrical Drives and Motion, Ischia, Italy, pp 573-578, 18-20 June 2014.

[11] K. Menoufi, "Dust accumulation on the surface of photovoltaic panels: introducing the photovoltaic soiling index (PVSI)," Sustainability, vol. 9, pp. 1-12, June 2017.

[12] J.P. Storey, P.R. Wilson, "Improved optimization strategy for irradiance equalization in dynamic photovoltaic arrays," IEEE Transactions on Power Electronics, vol. 28, No. 6, pp. 2946-2956, June 2013.

[13] N. Alam, V. Coors, S. Zlatanova, P.J.M. Oosterom, "Shadow effect on photovoltaic potentiality analysis using 3d city models," International Archives of the Photogrammetry, Remote Sensing and Spatial Information Sciences, vol. XXXIXB8, Melbourne, Australia, pp. 209-214, Sept. 2012.

[14] P. Romano, R. Candela, M. Cardinale, V.L. Vigni, D. Musso, R. Sanseverino, "Optimization of photovoltaic energy production through an efficient switching matrix," Journal of Sustainable Development of Energy, Water and Environment Systems, vol. 1, No. 3, 227-236, 2013.

[15] C.S.J. Francisco, "Shadowing effect on the performance in solar PV cells," Master's Thesis, University of Gavle, 2015.

[16] C. Lee, J. Suh, Y. Choi, "Comparative study on module connections to minimize degradation of photovoltaic systems 
due to bird droppings," International Journal of Renewable Energy Research, vol. 8, No. 1, pp. 230-237, March 2018.

[17] L.N. Rao, S. Gairola, "PV system analysis under partial shading using a sine model," International Journal of Renewable Energy Research, vol. 8, No. 1, pp. 280-290, March 2018.

[18] M.R. Rashel, A. Albino, T. Gonçalves, M. Tlemçani, "MATLAB simulink modeling of photovoltaic cells for understanding shadow effect," 5th International Conference on Renewable Energy Research and Applications, Birmingham, UK, pp. 747-750, 20-23 November 2016.

[19] M.C.D. Piazza, G. Vitale, "Photovoltaic field emulation including dynamic and partial shadow conditions," Applied Energy, vol. 87, pp. 814-823, March 2010.

[20] M.R. Rashel, Md. T. Ahmed, T. Goncalves, M. Tlemcani, R. Melicio, "Analysis of environmental parameters sensitivity to improve modeling of a c-Si panel," Sensor Letters, vol. 16, No. 3, pp. 176-181, March 2018.

[21] S. Saraiva, R. Melicio, J.C.O Matias, J.P.S. Catalão, C. Cabrita, "Simulation and experimental results for a photovoltaic system formed by polycrystalline solar modules," 16th IEEE Mediterranean Electrotechnical Conference-MELECON, Medina Yasmine Hammamet, Tunisia, pp. 806-809, 25-28 March 2012.

[22] M.R. Rashel, J. Rifath, T. Gonçalves, M. Tlemçani, R. Melicio, "Sensitivity analysis through error function of Crystalline-Si photovoltaic cell model integrated in a smart grid," International Journal of Renewable Energy Research, vol. 7, No. 4, pp. 1926-1933, 2017.

[23] R.S. Anjos, R. Melicio, V.M.F. Mendes, H.M.I. Pousinho, "Crystalline silicon PV module under effect of shading simulation of the hot-spot condition," in: Technological Innovation for Smart Systems, SPRINGER, vol. 499, pp. 479-487, 2017.

[24] Kh. Nada, M.A. Alrikabi, "Renewable energy types," Journal of Clean Energy Technologies, vol. 2, No. 1, pp. 61-64, January 2014.

[25] L.A.P. Fialho, R. Melício, V.M.F. Mendes, S. Viana, C. Rodrigues, A. Estanqueiro, "A simulation of integrated photovoltaic conversion into electric grid," Solar Energy, vol. 110, pp. 578-594, December 2014.

[26] J. Cubas, S. Pindado, A. Farrahi, "New method for analytical photovoltaic parameter extraction," International Conference on Renewable Energy and Application, Madrid, Spain, pp. 873-877, 20-23 October 2013.

[27] A. Einstein, "On a heuristic point of view concerning the production and transformation of light," Annalen der Physik, vol. 17, No. 132, pp. 1-16, Bern, March 1905.

[28] D. Bonkoungou, Z. Koalaga, D. Njomo, "Modelling and simulation of photovoltaic module considering single diode equivalent circuit model in MATLAB," International Journal of Emerging Technology and Advanced Engineering, vol. 3, No. 3, 593-502, 2013.

[29] M.R. Rashel, A. Albino, T. Goncalves, M. Tlemcani, "Sensitivity analysis of parameters of a photovoltaic cell under different condition," 10th International Conference on Software, Knowledge, Information Management \& Applications, Chengdu, China, pp. 333-337, 15-17 December 2016.

[30] A. Bari, J. Jiang, W. Saad, A. Jaekel, "Challenges in the smart grid applications: an overview," International Journal of Distributed Sensor Networks, vol. 2014, pp. 1-11, February 2014. [31] N.C. Batista, R. Melício, V.M.F. Mendes, "Layered smart grid architecture approach and field tests by zigbee technology," Energy Conversion and Management, vol. 88, pp. 49-59, December 2014.

[32] X. Fang, S. Misra, G. Xue, D. Yang, "Smart grid-the new and improved power grid: a survey," IEEE Communications Surveys \& Tutorials, vol. 14, No. 4, pp. 944-980, December 2011.

[33] G. Lobaccaro, S. Carlucci, E. Löfström, "A review of systems and technologies for smart homes and smart grids," Energies, vol. 9, No. 5, pp. 1-33, May 2016.

[34] E.M.G. Rodrigues, R. Melicio, V.M.F Mendes, J.P.S. Catalão, "Simulation of a solar cell considering single-diode equivalent circuit model", International Conference on Renewable Energies and Power Quality, Las Palmas de Gran Canaria, Spain, pp. 369-373, April 2011.

[35] A. Chatterjee, A. Keyhani, D. Kapoor, "Identification of photovoltaic source models," IEEE Transactions on Energy Conversion, vol. 26, No. 3, pp. 883-889, June 2011.

[36] N. Aoun, R. Chenni, B. Nahman, K. Bouchouicha, "Evaluation and validation of equivalent five-parameter model performance for photovoltaic panels using only reference data," Energy and Power Engineering, vol. 6, pp. 235-245, September 2014.

[37] T. Selmi, M. Abdul- Niby, M. Alameen, "Analysis and investigation of a two-diode solar cell using MATLAB/Simulink,", International Journal of Renewable Energy Research, vol. 4, No. 1, pp. 99-102, February 2014.

[38] F. Ghani, G. Rosengarten, M. Duke, J.K. Carson, "The numerical calculation of single-diode solar-cell modelling parameters," Renewable Energy, vol. 72, pp. 105-112, December 2014.

[39] D. Sera, R. Teodorescu, P. Rodriguez, "PV panel model based on datasheet values," IEEE International Symposium on Industrial Electronics, Vigo, Spain, pp. 2392-2396, 4-7 June 2007.

[40] R. Chenni, M. Makhlouf, T. Kerbache, A. Bouzid, "A detailed modeling method for photovoltaic cells," Energy, vol. 32, No. 9, pp. 1724-1730, September 2007.

[41] S. Lineykin, M. Averbukh, A. Kuperman, "Five-parameter model of photovoltaic cell based on STC data and dimensionless," IEEE 27th Convention of Electrical and Electronics Engineers in Israel, Eliat, Israel, pp. 1-5, 14-17 November 2012.

[42] A.A. El Tayyan, "PV system behavior based on datasheet," Journal of Electron Devices, vol. 9, pp. 335-341, February 2012. [43] S.A. Kalogirou, Solar Energy Engineering, 2nd Edition, Elsevier, November 2013.

[44] G.A. Migan, "Study of the operating temperature of a PV module," Dept. of Energy Sciences, Faculty of Engineering, Lund University, May 2013.

[45] V.J. Fesharaki, M. Dehghani, J.J. Fesharaki, "The effect of temperature on photovoltaic cell efficiency," 1st International Conference on Emerging Trends in Energy Conservation, Teheran, Iran, pp. 1-6, 20-21 November 2011.

[46] A.M. Humada, M. Hojabri, M.B. Mohamed, M.N. Ahmed, M.H. Bin Sulaiman, "A new method of PV reconfiguration under partial shadow conditions based on dc/dc central converter," International Journal of Renewable Energy Resources, vol. 4, pp. 49-53, 2014.

[47] A.A. El. Tayyan, "A simple method to extract the parameters of the spaced

-diode model of a PV system," Turkish Journal of Physics, vol. 37, pp. 121-131, March 2013.

[48] MathWorks, Solar cell, URL:

https://www.mathworks.com/help/physmod/elec/ref/solarcell.ht $\mathrm{ml}$ ? searchHighlight $=$ solar\%20cell\&s_tid $=$ doc_srchtitle

(Accessed:03.02.2018).

[49] C. Honsberg, S. Bowden, "Double diode model," PV Education,

URL:https://www.pveducation.org/pvedrom/characterisation/do uble-diode-model (Accessed:01.03.2017).

[50] L.A.P. Fialho, R. Melício, V.M.F. Mendes, A. Estanqueiro, "Simulation of a-Si PV system grid connected by boost and inverter," International Journal of Renewable Energy Research, vol. 5, No. 2, pp. 443-451, May 2015.

[51] M.R. Rashel, R. Melicio, M. Tlemcani, T. Goncalves, "Modeling and Simulation of PV Panel Under Different Internal and Environmental Conditions with Non-constant Load," In: Camarinha-Matos L., Almeida R., Oliveira J. (eds) Technological Innovation for Industry and Service Systems. DoCEIS 2019. IFIP Advances in Information and Communication Technology, vol 553. Springer, Cham 